\title{
Comment on Cho et al.: Usefulness of FDG PET/CT in determining benign from malignant endobronchial obstruction
}

\author{
Astrid A. M. van der Veldt • Mark Lubberink • \\ Adriaan A. Lammertsma • Egbert F. Smit
}

Received: 26 March 2011 /Accepted: 23 April 2011 /Published online: 18 June 2011

(C) The Author(s) 2011. This article is published with open access at Springerlink.com

Dear Sir,

With interest we read the study by Cho et al [1], evaluating the usefulness of FDG PET/CT for differentiating malignant endobronchial lesions with distal atelectasis from benign bronchial stenosis. In this retrospective study, they adequately demonstrated the additional value of FDG PET/ $\mathrm{CT}$ in this challenging clinical problem. Besides differentiation of endobronchial lesions, accurate discrimination between malignant tumours and atelectatic lung tissue can facilitate the definition of radiotherapy target volumes. As a result, the size of radiotherapy fields can be decreased [2], potentially reducing radiotherapy-induced side-effects.

A reply to this letter can be found at doi:10.1007/s00330-011-2170-y.

A. A. M. van der Veldt $(\bowtie) \cdot$ M. Lubberink $\cdot$ A. A. Lammertsma Department of Nuclear Medicine \& PET Research,

VU University Medical Center,

P.O. Box 7057, 1007 MB Amsterdam, The Netherlands

e-mail: aam.vanderveldt@vumc.nl

\section{E. F. Smit}

Department of Pulmonary Diseases,

VU University Medical Center,

Amsterdam, The Netherlands
For these purposes, the PET technique may be of additional value to discriminate the obstructive lesion from the atelectatic lung tissue. Although Cho et al [1] mentioned different patterns of FDG uptake in atelectatic lung tissue, we wonder whether the FDG uptake in the obstructive lesions could be adequately distinguished from the FDG uptake in the atelectatic lung tissue. As FDG uptake is dependent on perfusion for its delivery to tissue, variation in tissue vascularity may contribute to variable FDG uptake in obstructive atelectasis. In a previous PET/ CT study, we quantified tumour perfusion in lung cancer patients using radiolabelled water $\left(\left[{ }^{15} \mathrm{O}\right] \mathrm{H}_{2} \mathrm{O}\right)$ [3]. The measured perfusion values in atelectatic lung tissue differed significantly as compared with perfusion values in malignant tumours. Figure 1 shows an example of a patient with relatively high perfusion in atelectatic lung tissue as compared with the malignant tumour. These observations suggest that perfusion measurements may have additional value to discriminate atelectatic lung tissue from malignant lesions. Therefore, we believe that additional perfusion measurements of atelectatic lung tissue may improve diagnosis and radiotherapy planning of malignant endobronchial lesions. 

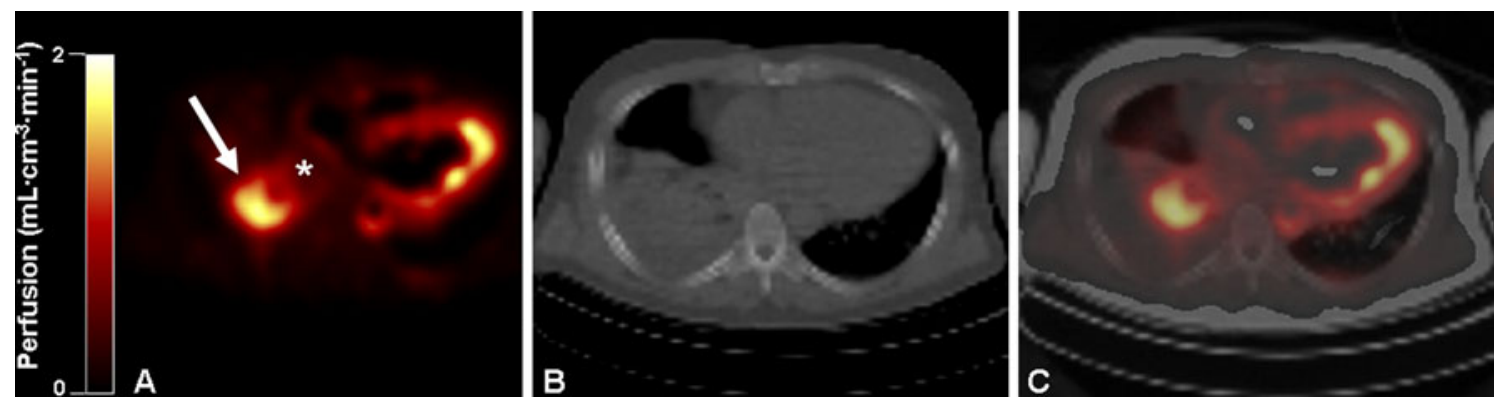

Fig. 1 PET-CT images of obstructive atelectasis in a 52-year old male patient with metastatic non-small cell lung cancer. The parametric perfusion image in Fig. 1a demonstrates high perfusion (arrow) in

obstruction atelectasis, whereas the perfusion in the primary tumour $(*)$ is substantially lower. Figs. $1 \mathbf{b}$ and $\mathbf{c}$ represent corresponding lowdose CT and fused PET-CT images, respectively

Open Access This article is distributed under the terms of the Creative Commons Attribution Noncommercial License which permits any noncommercial use, distribution, and reproduction in any medium, provided the original author(s) and source are credited.

\section{References}

1. Cho A, Hur J, Kang WJ, Cho HJ, Lee JH, Yun M, Lee JD (2011) Usefulness of FDG PET/CT in determining benign from malignant endobronchial obstruction. Eur Radiol 21:1077-1087. doi:10.1007/ s00330-010-2006-1

2. Nestle U, Walter K, Schmidt S, Licht N, Nieder C, Motaref B, Hellwig D, Niewald M, Ukena D, Kirsch CM, Sybrecht GW, Schnabel K (1999) 18F-deoxyglucose positron emission tomography (FDG-PET) for the planning of radiotherapy in lung cancer: high impact in patients with atelectasis. Int J Radiat Oncol Biol Phys 44:593-597

3. Van der Veldt AA, Hendrikse NH, Harms HJ, Comans EF, Postmus PE, Smit EF, Lammertsma AA, Lubberink M (2010) Quantitative parametric perfusion images using 15O-labeled water and a clinical PET/CT scanner: test-retest variability in lung cancer. J Nucl Med 51:1684-1690 